changed very little in the last thirty years. His humour had a certain Churchillian quality and like that great man he was great enough and honest enough to be able to make a joke at his own expense or to confess to some minor fault in technique which frequently untied the tongues of more reticent members to the great advantage of the meeting. His contributions to debate always had the flavour of originality, coupled with much wisdom, learning, and common sense, while his wide experience and keen observation enabled him to shed light on any subject. Many of us owe a debt of gratitude to Butler for his "Illustrated Guide to the Slit-lamp" which was the first original book on the subject in English. It was characteristic of him that he always referred to his book as the "Child's Guide to Knowledge," thus refusing to accept a pedestal to which it might well have entitled him.

Butler was perhaps seen at his best at the Oxford Congress which he served with,great devotion and enthusiasm from its inception. He read the Doyne Memorial Lecture in 1924. As a member of the Council since 1917 he seldom missed a Meeting and his contributions to the deliberations of that body were largely-responsible for the success of the annual meetings, both on the academic and social side. At the Congress itself his many papers showed a genius in the selection and presentation of subjects which would stimulate lively discussion and evoke valuable comment even from many of the more diffident and less vocal members. On the social side his confiding friendliness and infectious good humour made him a centre of affection and amusement, which added so much to that happy family atmosphere which has always been such a delightful feature at Oxford.

Our sympathy goes out to his wife, to whose devotion and help he owed so much and to his family. May those great qualitieswhich endeared him to so many of his colleagues be an abiding memory and consolation to them all.

\title{
JOHN LOCKHART GIBSON
}

THE death of Mr. Lockhart Gibson on September 30, 1944 was noted in our December issue. We are now able to give some details of his career, thanks to the courtesy of his son Dr. Walter Lockhart Gibson, who has'sent us a copy of the notice in the Medical Journal of Australia. Our facts are taken from this source with acknowledgements to the editor.

John Lockhàrt Gibson, who had been our Brisbane correspondent since our start in 1917; was of Scottish extraction and born at Ipswich, Queensland in 1860. His education was at the Ipswich Grammar School and his medical training was from Edinburgh. He had a brilliant academic career in Edinburgh and deputised for Professor Rutherford in giving the lectures in physiology when the 
latter was taken ill. He put in post-graduate classes in London, Berlin and Vienna before returning $t$ home. He was offered a post as physiologist in one of the London medical schools, but preferred to return to the land of his birth. He began in general practice in Brisbane and we gather that his position at this time was not too easy on account of his high scientific training which was not altogether appreciated by the more elderly of his colleagues. $\mathrm{He}$ was on the staff of the hospital for sick children but a breakdown in health put him out of service for a year and a half and he decided to give up general practice and contine himself to ophthalmology. Here he at once made his mark and his work with Dr. Jefferis Turner on ocular plumbism was of the greatest importance. In 19.15 he was in charge of the ophthalmological department at Mudros and to the end of his life was active in the interests of repatriated soldiers. For many years also he was a member of the Australasian Medical Publishing .Co.

He was the author of numerous papers on ophthalmology as wetl as some-earlier ones in anatomy and physiology. It will be recalled that he wrote on ocular plumbism in children in this Journal in 1931. Mr. Lockhart Gibson died in harness while president of the Ophthalmological Society of Australia.

\section{NOTES} Association for the THE 14th Annual Report for the year ending
March 31, 1944, covers much the same ground

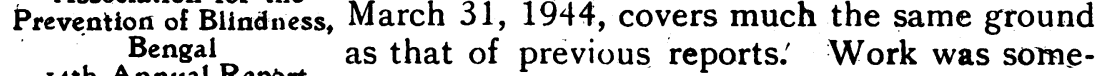
r4th Annual Report what curtailed by war conditions and by the famine crisis, but five travelling eye dispensaries have been at work throughout the year. This is the minimum requirement for so large a province. The report emphasises the importance of preven. tion in ophthalmology which is summed up under three headings, viz.-Improvement of ophthalmic services; Education of the public; Research. During the year Sir Clutha Mackenzie, of St. Dunstan's, who was appointed a special officer by the Government of India, submitted a comprehensive report on blindness and welfare of the blind in India to the Government. The latter, in the department of education, health and lands, appointed a committee to consider this report and to formulate ways and means as to how best to give practical shape to his recommendations. Lt.-Col. E. O.'G. Kirwan, C.I.E. represents the association on this Committee. The usual appendices conclude the report.

Special Notice

WE are asked by the Ministry of Information to state that the fact that goods made of raw materials in short supply owing to war conditions are advertised in this journal should not be taken as an indication that they are necessarily available for export. 